\title{
Lesser Prairie-Chicken Hen and Brood Habitat Use on Sand Shinnery Oak
}

\author{
Luke A. Bell, ${ }^{1}$ Samuel D. Fublendorf, ${ }^{2}$ Michael A. Patten, ${ }^{3,6}$ Donald H. Wolfe, ${ }^{4}$ and Steve K. Sherrod ${ }^{5}$ \\ Authors are ${ }^{1}$ Fish and Wildlife Biologist, and ${ }^{2}$ Professor, Natural Resource Ecology and Management, Oklahoma State University, Stillwater, OK 74078, \\ USA; ${ }^{3}$ Director of Research, ${ }^{4}$ Wildlife Biologist, and ${ }^{5}$ Executive Director, Sutton Avian Research Center, University of Oklahoma, P.O. Box 2007, \\ Bartlesville, OK 74005, USA; and ${ }^{6}$ Associate Professor, Oklahoma Biological Survey, University of Oklahoma, Norman, OK 73019, USA.
}

\begin{abstract}
The structural attributes of shrubland communities may provide thermal refugia and protective cover necessary for wild animals to survive. During the summers of 2002 and 2003, we evaluated the thermal environment for lesser prairie-chicken (Tympanuchus pallidicinctus Ridgway) broods in southeast New Mexico across a complex landscape that included grazed sand shinnery oak (Quercus havardii Rydb.), ungrazed sand shinnery oak treated with tebuthiuron, sand dunes, cropland, and Conservation Reserve Program native grass plantings. Based on data from 257 brood locations and 53 random locations, lesser prairie-chicken broods selected locations based on sand shinnery oak dominance, with taller plant heights and more over-head cover, when temperatures exceeded $26.4^{\circ} \mathrm{C}$ than what was randomly available. Prairie chickens selected areas not treated with herbicide and these sites were often selected at a fine spatial scale. These data support other studies suggesting that there may be no justification of shrub control for lesser prairie-chicken conservation within the sand shinnery oak communities.
\end{abstract}

\section{Resumen}

Las características estructurales de las comunidades de plantas arbustivas podrían proveer refugios térmicos y cobertura de protección necesaria para la supervivencia de animales salvajes. Durante los veranos del 2002 y 2003, evaluamos el ambiente térmico para polluelos de gallinas de la pradera (Tympanuchus pallidicinctus Ridgway) en el sureste de Nuevo México a través de un complejo paisaje que incluyó encino chaparro (Quercus havardii Rydb.) bajo pastoreo, encino chaparro sin pastoreo tratado con tebuthiuron, dunas de arena, tierras de cultivo y plantaciones de pastos nativos del programa de Conservation Reserve Program. Basándose en información proveniente de 257 lugares de cría y 53 lugares escogidos al azar, los polluelos de las gallinas de la pradera provenientes de nidos seleccionaron lugares donde dominaba el encino chaparro con plantas altas con cobertura que alcanzaba alturas superiores a la altura de la cabeza cuando las temperaturas excedían los $26.4^{\circ} \mathrm{C}$ comparados con los lugares que fueron dispuestos al azar. Las gallinas de la pradera seleccionaron áreas no tratadas con herbicidas y estos sitios fueron a menudo seleccionados en una escala espacial fina. Estos datos apoyan otros estudios que sugieren que puede ser que no exista justificación para el control de arbustos para la conservación de polluelos de gallinas de la pradera dentro de comunidades de encino chaparro.

Key Words: lesser prairie-chicken, sand shinnery oak, tebuthiuron

\section{INTRODUCTION}

Shrublands of North America's Great Plains are some of the most imperiled ecosystems in the world (Samson and Knopf 1994). For example, in the past $100 \mathrm{yr}$ more than 500,000 ha of sand shinnery oak communities have been converted to cropland or grassland in the southern Great Plains (Peterson and Boyd 1998). Some conversions were conducted as habitat improvement and conservation efforts to benefit select wildlife (Doerr and Guthery 1983; Olawsky and Smith 1991) or increase grass production for domestic livestock; however, decline in sand shinnery oak (Quercus havardii) communities

Research was funded in part by the New Mexico Dept of Game and Fish, US Fish and Wildlife Service, National Fish and Wild life Foundation, University of Oklahoma, Grasslans Charitable Foundation, and ConocoPhillips.

The views described herein are those of the authors and do not necessarily reflect the views of the US Fish and Wildlife Service.

At the time of the research, the senior author was a research assistant, Natural Resource Ecology and Management, Oklahoma State University, Stillwater, OK 74078, USA.

Correspondence: Luke A. Bell, US Fish and Wildlife Service, 9014 E 21st St, Tulsa, OK 74129, USA. Email: luke_bell@fws.gov

Manuscript received 17 December 2008; manuscript accepted 21 April 2010. has led to the decline or displacement of other species within this region (Degenhardt and Jones 1972; Willig et al. 1993; Johnson et al. 2004). As an example, the lesser prairie-chicken (Tympanuchus pallidicinctus) occupies only $18 \%$ of its historical range as of 1963 , with an additional loss of $78 \%$ from 1963 to 1980 (Crawford 1980; Taylor and Guthery 1980). Population declines are largely correlated with declines in native shrubland communities, including sand shinnery oak (Peterson and Boyd 1998; Bailey and Williams 2000; Sullivan et al. 2000).

It has been a common practice to control the oak under the guise of prairie-chicken conservation (Doerr and Guthery 1983; Olawsky and Smith 1991). It has been suggested that reducing dominance of sand shinnery oak benefits lesser prairie-chickens (Doerr and Guthery 1983; Olawsky and Smith 1991). Permanently removing sand shinnery oak with herbicides might be detrimental to the birds because 1) the oak is a rhizomatous shrub that reproduces slowly and does not invade previously unoccupied areas (Wiedeman 1960; Dhillion et al. 1994); 2) the oak is part of a rapid decline of plant communities associated with North America's diminishing Great Plains (Samson and Knopf 1994; Peterson and Boyd 1998); 3) lesser 
Table 1. Descriptions of cover types and grouped categories used to interpret aerial photography (2004) for classification of landscapes within $4.8 \mathrm{~km}$ of trapped lesser prairie-chickens from seven leks in New Mexico.

\begin{tabular}{|c|c|c|c|c|c|}
\hline Class & Classification & Grazing use & Herbicide use & Area (ha) & Description of dominant features \\
\hline \multicolumn{6}{|c|}{ Cover type } \\
\hline 1 & Ungrazed sand shinnery oak & No & No & 2062 & $\begin{array}{l}\text { Sand shinnery oak and native grasses }<18 \% \text {, owned by New Mexico } \\
\text { Game Commission }\end{array}$ \\
\hline 2 & Treated sand shinnery oak & No & Yes & 2998 & $\begin{array}{l}\text { Tebuthiuron treated sand shinnery oak with scattered untreated sand } \\
\text { dunes }\end{array}$ \\
\hline 3 & Grazed sand shinnery oak & Yes & No & 9411 & Sand shinnery oak with $<3 \%$ native grass cover \\
\hline 4 & $\begin{array}{l}\text { Conservation Reserve } \\
\text { Program (CRP) }\end{array}$ & No & No & 137 & Native grass mix \\
\hline 5 & Other & Yes/No & Yes/No & 9433 & Conglomeration of cropland, fallow fields, oil pads, and old homesteads \\
\hline 6 & Ungrazed sand dunes & No & No & 96 & Untreated sand dunes on tebuthiuron treated area \\
\hline 7 & Grazed sand dunes & Yes & No & 347 & Sand dunes on grazed sand shinnery oak pastures \\
\hline \multicolumn{6}{|c|}{ Grouped categories $^{1}$} \\
\hline & Ungrazed no herbicide & No & No & 2158 & Sand shinnery oak without grazing (Includes 1 and 6) \\
\hline & Ungrazed herbicide & No & Yes & 3135 & $\begin{array}{l}\text { Tebuthiuron treated sand shinnery oak and CRP without grazing (Includes } \\
2 \text { and 4) }\end{array}$ \\
\hline & Grazed no herbicide & Yes & No & 9758 & Sand shinnery oak with <3\% native grass cover (Includes 3 and 7) \\
\hline
\end{tabular}

1"Other" cover type was left out of category grouping because no data were collected on these areas.

prairie-chickens have been repeatedly documented to be dependent on shrublands across their range (Copelin 1963; Olawsky and Smith 1991; Boyd and Bidwell 2001; Fuhlendorf et al. 2002; Patten et al. 2005); and 4) oak removal is often based on the false premise that this shrub is a woody invasive species that has increased in extent since settlement because of fire suppression (York and Dick-Peddie 1969). Herbicides (primarily tebuthiuron) have been used to reduce the dominance of oaks in an attempt to restore these ecosystems to hypothesized presettlement vegetation dependent on frequent fires for maintaining its low stature (Doerr and Guthery 1983; Olawsky and Smith 1991; Patten et al. 2005). Yet a single application of tebuthiuron can permanently eradicate sand shinnery oak and other shrubs from shrubland ecosystems (Pettit 1979; Jones and Pettit 1984). Prescribed fire, on the other hand, only temporarily reduces dominance of aboveground portions of sand shinnery oaks, and the fire-tolerant plants recover in 2-3 yr (Boyd and Bidwell 2001; Harrell et al. 2001). Because the oaks and other native shrubs, especially sand sagebrush (Artemisia filifolia Torr.), are important for providing necessary microhabitat and microclimate characteristics for lesser prairie-chickens across their range (Copelin 1963; Olawsky and Smith 1991; Boyd and Bidwell 2001; Fuhlendorf et al. 2002; Patten et al. 2005), conservationists should closely examine land management practices that eradicate them or that create permanent changes to vegetation structure and composition.

Our study system allowed us to evaluate lesser prairiechicken populations from a landscape perspective in an area dominated by public and private rangelands that vary in grazing and herbicide application. Our specific objectives within the three dominate land management practices were 1) to determine if hens with broods selected locations differing in thermal microclimate from random locations, and 2) to determine the effects of herbicides, which are used commonly as surrogates for historical fire regimes, and other land management practices on brood-rearing habitat.

\section{METHODS}

\section{Study Area}

Our 24484 -ha study area (lat $33^{\circ} 40^{\prime} \mathrm{N}$, long $103^{\circ} 06^{\prime} \mathrm{W}$ ) was located in southern Roosevelt County, New Mexico. Sand shinnery oak communities dominated the landscape but were fragmented by cultivation and herbicide application to native stands of oak (Table 1). Other common shrubs and subshrubs included honey mesquite (Prosopis glandulosa Torr.), cholla (Opuntia imbricata [Haw.] F.M. Knuth), broom snakeweed (Gutierrezia sarothrae [Pursh] Britton and Rusby), and yucca (Yucca glauca Nutt.). Common grasses were sand bluestem (Andropogon hallii Hack.); little bluestem (Schizachyrium scoparium [Michx.] Nash); blue (Bouteloua gracilis [Willd. ex Kunth] Lag. ex Griffiths), black (Bouteloua eriopoda [Torr.] Torr), and sideoats (Bouteloua curtipendula [Michx.] Torr.) gramas; sand dropseed (Sporobolus cryptandrus [Torr.] A. Gray); and purple three-awn (Aristida purpurea Nutt.). Common forbs were western ragweed (Ambrosia psilostachya DC.), annual wild buckwheat (Polygonum convolvulus L.), and camphorweed (Heterotheca latifolia [Lam.] Britton and Rusby). Peterson and Boyd (1998) provide a comprehensive list of plants associated with sand shinnery oak communities relevant to the study area.

Climate in the area was semiarid continental with an average frost-free growing period of $200 \mathrm{~d}$ extending from mid April to late October (Wright 2003). Average annual precipitation was $41 \mathrm{~cm}$, with $85 \%$ falling as rain from April through October, and average annual temperature was $15^{\circ} \mathrm{C}$ with lows of $-34^{\circ} \mathrm{C}$ and highs $>40^{\circ} \mathrm{C}$ (Wright 2003). Soil textures varied from sand to sandy clay loam, and elevation ranged from $1080 \mathrm{~m}$ to $1300 \mathrm{~m}$, with minimal slopes and dune complexes (Wright 2003).

\section{Hen and Brood Monitoring}

During autumns of 1999 and 2001 and springs of 1999-2003, the Sutton Avian Research Center trapped adult lesser prairie- 
chickens on their breeding grounds (leks) using walk-in funnel traps (25 traps per lek) connected by 8-m lengths of drift fence in large "W" arrays (Haukos et al. 1990; Schroeder and Braun 1991). Birds were weighed, measured, and fitted with a 15 -g ( $\leq 2 \%$ of the bird's weight) bib-mounted radiotransmitter with a loop antenna (Telemetry Solutions, Inc., Concord, CA, and Wildlife Materials, Inc., Murphysboro, IL). Previous studies on telemetered lesser prairie-chickens indicate a strong tendency to remain within $4.8 \mathrm{~km}$ of a lek (Taylor and Guthery 1980; Giesen 1994; Riley et al. 1994). Within this distance from the leks, hens with broods had equal opportunity to select any of three dominant cover types-ungrazed + no herbicide, ungrazed +herbicide, and grazed + no herbicide-including reduced and intact sand shinnery oak communities (Table 1).

During the 2002 and 2003 study reported herein, we tracked 72 hens, identifying 61 nests and 19 broods (plus five broods from unmarked hens). We followed all hens with broods until no chicks remained for a total of 257 visual confirmations on the 24 broods.

\section{Microclimate and Habitat Sampling}

After eggs hatched, we followed each brood three to four times per week and no more than once per day for 9-10 wk from late May to early August each year. To minimize disturbance of hens with broods, we only recorded date, time, dominant cover type, temperature, observer, and Global Positioning System (GPS) coordinates with a brief description of the brood's location. Exact chick locations were deciphered by examining footprints or locating chick dug-out depressions in sandy areas, usually within a few meters of the hen, and chicks remained within 1-2 $\mathrm{m}$ of each other. We used a handheld weather device (Kestrel 3000, Kestrel Meters Co., Minneapolis, MN) to collect a 30 -s average temperature at chick height $(10 \mathrm{~cm}$ above ground) at the exact point where a chick was found, such as dug-out depressions in the shade of shrubs. If broods did not flush, we recorded temperature information in visually similar habitat closest to the brood (usually within $5 \mathrm{~m}$ of a brood). Vegetation was sampled the following day using the GPS coordinates and location description from a previous tracking event.

We used the line point method to estimate basal vegetation cover; a line's midpoint was centered on the location of a brood or of a random GPS point. We recorded measurements at 1-m intervals along the $10-\mathrm{m}$ transect by holding an aluminum rod, measuring $6.4 \mathrm{~mm}$ in diameter $\times 1.2 \mathrm{~m}$ in length, vertically through the vegetation (Heady et al. 1959; Wiens 1974). We measured and identified plant species information for both the highest plant part (e.g., leaf or stem) touching the $\operatorname{rod} \geq 20 \mathrm{~cm}$ above ground (height of an adult lesser prairie-chicken) for canopy cover and basal cover contacts. Basal cover contacts were recorded when the rod's tip touched a plant's basal area. For canopy and basal cover contacts, we combined species data into categories: tallgrass (sand bluestem, little bluestem, sideoats grama, and sand dropseed), other grass, sand shinnery oak, sand sagebrush, mesquite, and other shrubs. At $0 \mathrm{~m}, 5 \mathrm{~m}$, and $10 \mathrm{~m}$ along the sample line, we recorded stem density for each plant category in a circular $0.5-\mathrm{m}$ radius plot and tallest plant part within a 1-m radius. All plant parts touching the rod were recorded within three vertical strata $(<10 \mathrm{~cm}, 10-50 \mathrm{~cm}$, and $>50 \mathrm{~cm}$ above ground; Wiens 1974) at each 5 -m interval. In 2003 we recorded angle of obstruction (Kopp et al. 1998; Harrell and Fuhlendorf 2002) at 5-m intervals along brood and random transects.

In order to compare microclimate and habitat information among random transects in each land management practice and brood use locations simultaneously, we placed HOBO dataloggers (Onset Computer Corp., Bourne, MA) $1 \mathrm{~m}$ apart in three separate $10-\mathrm{m}$ random transects $(n=11$ points), one transect in each management area. We followed the same procedures to sample plant information at random locations that were used for brood locations. Plant information was only collected on the day we established the random transect of dataloggers since the vegetation did not change over the sampling period. Dataloggers recorded temperature and relative humidity at 15 -min intervals for $1 \mathrm{wk}$ and were mounted atop 10-cm (chick height) wooden stakes covered with white plastic guttering material for protection against mud, debris, and direct sunlight exposure. After $7 \mathrm{~d}$, data were downloaded and we moved dataloggers to new random locations within the same land management type. Not all transects successfully recorded temperature for $7 \mathrm{~d}$ because some transects were damaged by cattle or a variety of other disturbances. If we could determine that transects had quality information up to a specific date and time, then we used the information from a partial sample, creating an unbalanced design. We located transects at 53 randomly generated GPS points at sites managed as follows: grazed + no herbicide $(n=15)$, ungrazed + no herbicide $(n=28)$, and ungrazed + herbicide $(n=10$; see Table 1 for area calculations of management sites). Grazed sites were stocked continuously at rates of 0.81 2.63 ha per animal unit month (Wright 2003).

\section{Habitat Mapping}

To address collective habitat use vs. collective habitat availability (Thomas and Taylor 2006), we mapped all landscapes within $4.8 \mathrm{~km}$ of the seven leks used by trapped lesser prairie-chickens (Table 1). Lesser prairie-chickens have a tendency to remain within $4.8 \mathrm{~km}$ of leks, so all vegetation within this distance of leks (map extent $=24484$ ha) was mapped from interpretation of a 1-m color digital orthophoto quadrangle taken in the summer of 2004 (scale =1:5000). A GPS flight path for the February 2002 aerial application of tebuthiuron was scanned and geo-referenced (SATLOC MapStar 1.6.2.1, CSI Wireless, Inc., Scottsdale, AZ) to delineate the actual herbicide-treated area. Topographic quadrangle maps $($ scale $=1: 24000)$ were used for geo-registration. All photo interpretation was verified by site visits. Habitat types were constructed using onscreen digitizing through ArcView 3.3 software (Environmental Systems Research Institute, Inc. 1998) to identify landscapes including untreated sand dunes and herbicide treated areas.

To further evaluate effects of herbicide use on lesser prairiechicken brood habitat, we examined habitat use for a pasture that had herbicide applied to control sand shinnery oak (this area was within the study area). Herbicide application was not uniform: the pasture included sprayed $(72 \%)$ and unsprayed $(18 \%)$ areas. Four hens with broods occurred in the treated 
area. Within the pasture that had herbicides applied, we calculated availability of herbicide-treated areas and untreated sand dunes. The area was defined using a radius of $1.2 \mathrm{~km}$ (maximum distance broods traveled from nests) around nest locations, so the vegetation's map extent equaled 514 ha. All brood locations within this area and across the study site were assigned a habitat type based on the GPS coordinates and habitat type intersection. Habitat availability and use data for broods were analyzed with Ivlev's (1961) electivity index $[\mathrm{I}=\%$ used $-\%$ available $/(\%$ used $+\%$ available $)]$.

\section{Data Analyses}

For analyses, we categorized habitat variables into two spatial scales and two temperatures. Spatial scale categories were used only on vegetation data collected at brood locations for tests about spatially dependent vegetation-related habitat selection questions. Random habitat and temperature data were only analyzed at the line scale. Where applied, our "line" scale was the entire 10-m transect, whereas, at brood locations, our "point" scale was the midpoint of this transect (i.e., the brood location). Our temperature categories were defined as the temperature difference at random versus brood locations. Observations $(n=180)$ with a negative difference were categorized as "cool," whereas observations $(n=77)$ with a positive difference were categorized as "warm."

First, we calculated the difference between mean brood and mean random temperatures for simultaneous events. We regressed (proc glm, SAS Institute 2003) time of day against temperature for both brood and random locations and regressed mean temperature at random sites against the temperature difference described above.

Second, we separated brood locations into classified groups of spatial scale (point and line) and temperature (cool and warm). We used mixed-model analysis of variance (ANOVA; proc mixed, SAS Institute 2003) to test for differences between brood and random locations for each vegetation attribute at each scale and temperature category. The response variable was temperature, and brood vs. random, point vs. line, and cool vs. warm were treated as fixed effect predictors. We used Satterthwaite's approximation to correct for unbalanced design (Marasinghe and Kennedy 2008) and least squares means to conduct pairwise comparisons among classified groups.

Third, we compared all 23 vegetation and habitat structural variables collected at brood locations among each of the three land management practices. We compared the same information for brood and random locations within each land management practice during "cool" and "warm" time periods to identify which land management was most appropriate for brood habitat. The ANOVA was built as described above, but in this case we had an additional fixed effect predictor: land management type. Thus, we used data from each type on the same dates and times for both brood and random locations. We also used a comparable ANOVA model to analyze "cool" and "warm" temperatures from brood and random locations separately (proc mixed, SAS Institute 2003). As before, univariate analyses were most appropriate because of the number of variables compared to land management practices.

Finally, we constructed a mixed-model analysis of covariance (ANCOVA) to test for a difference in temperature between brood and random locations with time of day as a covariate (including a squared term of it), temperature as the response variable, and brood vs. random and its interactions with time of day and its square as predictors. We ran this ANCOVA separately for each of the three types of land management and with all types combined (i.e., in the latter test, we included land management type and its interactions as fixed effects).

\section{RESULTS}

\section{Objective 1: Temperature Selection}

Temperature varied within a $10-\mathrm{m}$ line: the greatest standard deviation in simultaneously recorded temperatures among the 11 dataloggers within random transects was $13^{\circ} \mathrm{C}$. Hens with broods selected habitat with temperatures different from random locations; the direction of differences depended on time of day and diurnal variation of temperature (Fig. 1a; $\left.\mathrm{F}_{1,255}=1688.8 ; P<0.0001\right)$. The difference between brood and random temperatures was negatively correlated with the temperature of random transects (Fig. $1 \mathrm{~b} ; r^{2}=0.50 ; y=7.39$ $[ \pm 0.57 \mathrm{SE}]-0.28 \times[ \pm 0.02 \mathrm{SE}] ; \quad P<0.0001)$, indicating broods select habitats that are warmer than random during cool times and cooler than random during warm times.

\section{Objective 2: Land Management Practices Compared to Brood Locations}

Vegetation attributes varied greatly among the three land management practices (Table 2). Total grass canopy cover was higher in the ungrazed +herbicide managed areas $(27.27 \% \pm 6.78 ; n=10$ transects) versus ungrazed + no herbicide $(16.56 \% \pm 3.03 ; n=28)$ and grazed + no herbicide $(2.42 \% \pm 1.07 ; n=15)$ sites. Sand shinnery oak canopy cover was lowest for sites with herbicide application $(3.64 \% \pm 2.78$; $n=10)$, and higher for ungrazed + no herbicide sites $(14.61 \% \pm$ $2.40 ; n=28)$ and grazed + no herbicide $(13.33 \% \pm 2.64$; $n=15$ ). Oak stem density (number of stems within a $0.5-\mathrm{m}$ radius) was highest with the presence of grazing and lowest under herbicide treated areas: $14.11 \pm 1.98$ on grazed + no herbicide and $2.87 \pm 1.50$ on ungrazed + herbicide, respectively.

Habitat structure varied among brood and random locations within land management practices (Tables 2). The greatest difference between brood and random locations within a site occurred on ungrazed + herbicide sites, where 10 (Table 2) of 23 habitat variables differed $(P \leq 0.05)$. In particular, percent canopy cover of the oak was $70 \%$ lower $(t=1.98$; $\mathrm{df}=304$; $P=0.05)$ on random versus brood locations for ungrazed + herbicide sites. Five habitat variables measured on ungrazed + no herbicide sites differed $(P \leq 0.05)$ between brood and random locations. Brood and random locations within grazed + no herbicide sites were most similar, with only three variables different from random. The tallest rod contact was lower on random sites than at brood locations $(t=2.04$; $\mathrm{df}=304 ; P=0.04)$.

For each management type, time of day and its square were associated significantly with temperature $(P<0.0001$ in all cases), so its use as a covariate was appropriate. Temperatures at brood vs. random locations differed significantly for each 

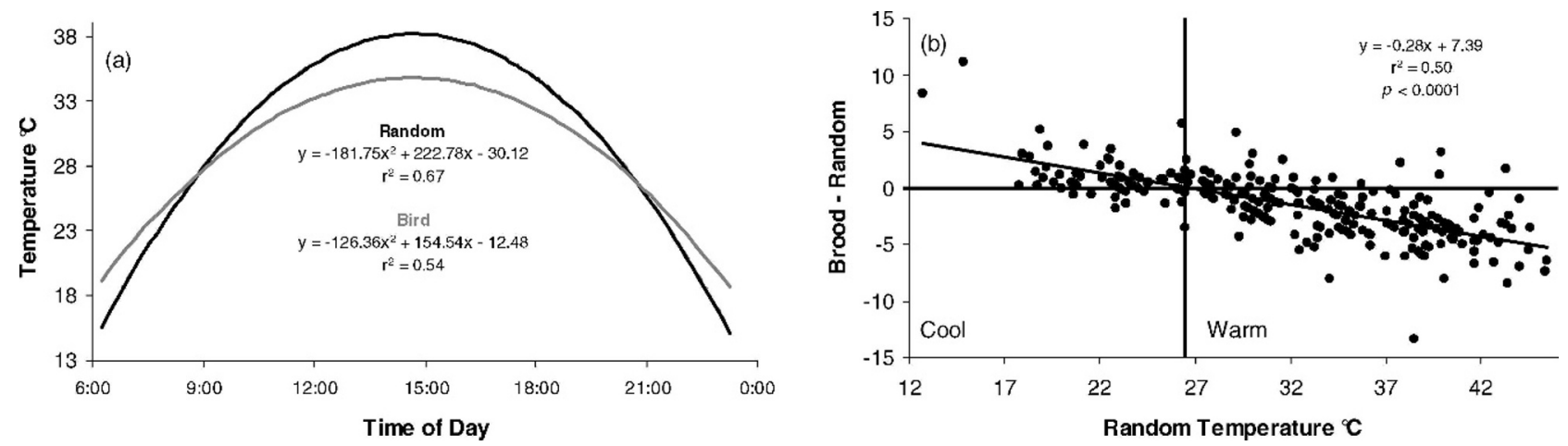

Figure 1. This figure demonstrates the selection of temperatures by broods that are counter in terms of what temperature is available at random locations: temperature at brood locations with corresponding random average temperature according to time of day (a) and temperature difference according to random average temperature (b) for brood locations in southeastern New Mexico, summers of 2002-2003. Figure 1b was used to separate brood locations into two categories of temperature selection as indicated by the vertical line that separates the graph into "cool" and "warm" time periods.

management type (grazed + no herbicide: $\mathrm{F}_{1,222}=5.98$, $P<0.02$; ungrazed + no herbicide: $\mathrm{F}_{1,78}=8.13, P<0.01$; ungrazed + herbicide: $\left.\mathrm{F}_{1,106}=5.35, P<0.03\right)$. For management type, interactions terms were significant $(P<0.03$ in all cases $)$ between brood vs. random and time of day and between brood vs. random and (time of day) ${ }^{2}$. Temperature between brood and random locations remained significantly different with data pooled across management types $\left(\mathrm{F}_{1,406}=13.74\right.$; $P=0.0002)$. There was also a difference among types $\left(\mathrm{F}_{2,406}=4.25 ; P<0.02\right)$, but none of the interaction terms involving management type $\times$ brood vs. random were significant $(P>0.19$ in all cases). As before, interaction terms with time of day were significant $(P<0.0001$ in all cases).

Broods preferred ungrazed + no herbicide sites across the entire study area (Ivlev's index $=0.6$ ) and within the herbicide treated pasture (Ivlev's index $=0.5$ ). For the study area, the second highest preferred land management practice was grazed + no herbicide sites (Ivlev's index $=0.1$ ) and ungrazed + herbicide sites (Ivlev's index $=-0.3$ ) were avoided. Within the confines of usable space of the herbicide treated pasture, ungrazed + no herbicide sites (i.e., dunes) were used the most (71\% of documented brood locations), whereas ungrazed+ herbicide sites were the most abundant $168 \%$ of available habitat) but least used (29\% of documented brood locations; Ivlev's index $=-0.4)$.

\section{DISCUSSION}

\section{Thermal and Habitat Selection}

Past and present research on the lesser prairie-chicken has described both sand sagebrush and sand shinnery oak shrublands as important habitats for thermal cover (Copelin 1963) and sustainability at multiple spatial scales (Woodward et al. 2001; Fuhlendorf et al. 2002; Patten et al. 2005). Broods had access to a variety of habitat types, from dense, ungrazed shrublands to lands treated with herbicides to heavily grazed prairie. Temperature collected by dataloggers within these sites at random locations differed from temperature at sites selected by broods. Differences depended on air temperatures and time of day. As defined by the thermal selection's $x$-intercept value
(Fig. 1b), when cool $\left(<26.4^{\circ} \mathrm{C}\right)$, broods selected warmer sites dominated by sand shinnery oak. When warm $\left(\geq 26.4^{\circ} \mathrm{C}\right)$, broods selected cooler sites also dominated by the oak but that were taller and denser than vegetation available at random. These differences imply that prairie-chickens selected for moderation of temperatures. However, because the oak is prevalent at both cool and warm sites, it is difficult to separate oak selection from thermal selection. The significance of the oak to brood habitat selection remains obscure: it may reflect thermal advantages (broods selecting for varying structural attributes within oak), but our data from each land management practice did not reveal thermal differences (Table 2).

Broods exhibited selection in all three land management practices. Selected locations were isolated to areas of living sand shinnery oak or on lands where sand shinnery oak was not permanently removed. For instance, 85 of the 257 brood locations were on ungrazed + herbicide sites, but $71 \%$ of these locations were restricted to sand dunes that missed herbicide application (i.e., living sand shinnery oak), and the remaining $29 \%$ were on treated areas during cool times of day when habitat selection is not influenced by heat. Per Ivlev's electivity index, ungrazed + herbicide sites were avoided, whereas untreated sand dunes were used frequently. Broods may select dunes because their topography offers protection from sun, but the importance of sand shinnery oak remains.

\section{Habitat Structure and Scale}

Sand shinnery oak communities provide structural attributes necessary for thermal refugia and other life requirements. For instance, relative to random or "cool" sites, plant density $>50 \mathrm{~cm}$ above ground and tall vegetation were more abundant at brood locations when temperatures at chick height exceeded $26.4^{\circ} \mathrm{C}$ (Fig. 2). Yet broods did not select different amounts of oak stem densities at different times of the day, but they did select sites where oak was more abundant than availability. Preference for shrubs demonstrates the importance of woody plants in creating thermal refugia, and our results are consistent with anecdotal observations of lesser prairie-chickens in western Oklahoma seeking shade in oak mottes (Donaldson 1969). 
Table 2. Comparison of all variables sampled at brood and random locations within each land management practice. Letters indicate variables significantly different from brood locations ( $\mathrm{h}=$ "higher than brood" and I = "lower than brood") in the same row. Brood and random locations within areas that were grazed without herbicide use were most similar for land management practice. Sites ungrazed and treated with herbicide contained the greatest difference for all variables measured at brood and random locations within these sites. On all three land management types, temperature did not differ between brood and random locations within each site during "cool" time periods. However, during "warm" time periods, temperatures on grazed sites without herbicide use were significantly hotter than brood locations.

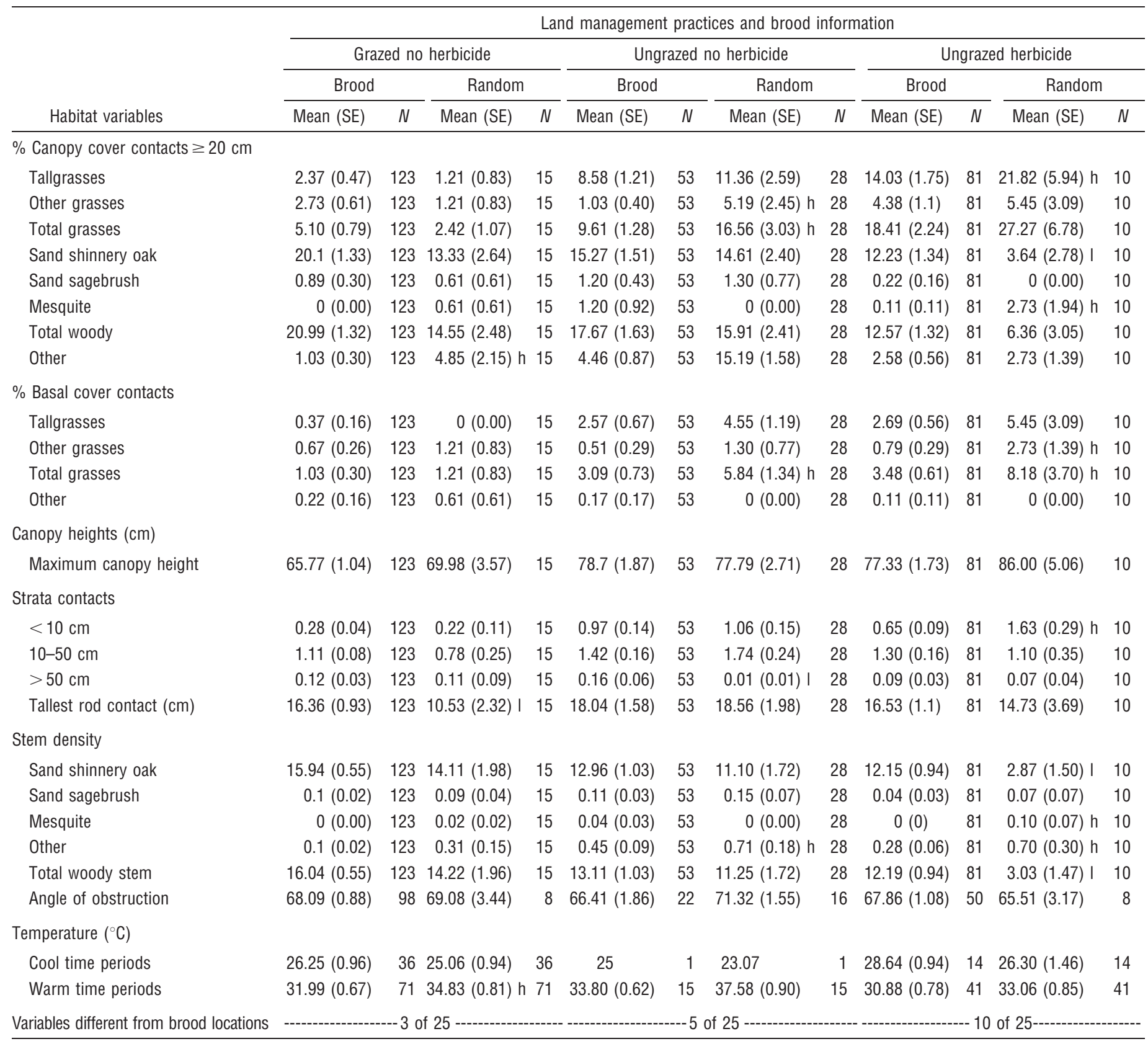

Habitat selection varied with spatial scale and temperature. At the point scale, broods selected taller and denser (at both $10-50 \mathrm{~cm}$ and $>50 \mathrm{~cm}$ above ground) vegetation than at the line scale and random sites. Also at the point scale, broods selected taller and denser $(50 \mathrm{~cm}$ above ground) vegetation when warm, thus demonstrating an interdependence of spatial scale and time of day. It was not surprising that heat avoidance behavior occurred at a small spatial scale because the landscape and brood sites were dominated by oak, so any habitat selection on the basis of temperature may be within a few meters. In addition, we found temperatures could vary greatly within a $10-\mathrm{m}$ line, further suggesting that habitat selection occurs at fine scales.

\section{Effects of Tebuthiuron on Sand Shinnery Oak}

The overall picture that arises from our study is that tebuthiuron reduces vegetation characteristics that lesser prairie-chicken broods utilize. Of the 23 habitat measures collected on tebuthiuron-treated sites, $40 \%$ of the measurements differed between brood and random locations. Te- 

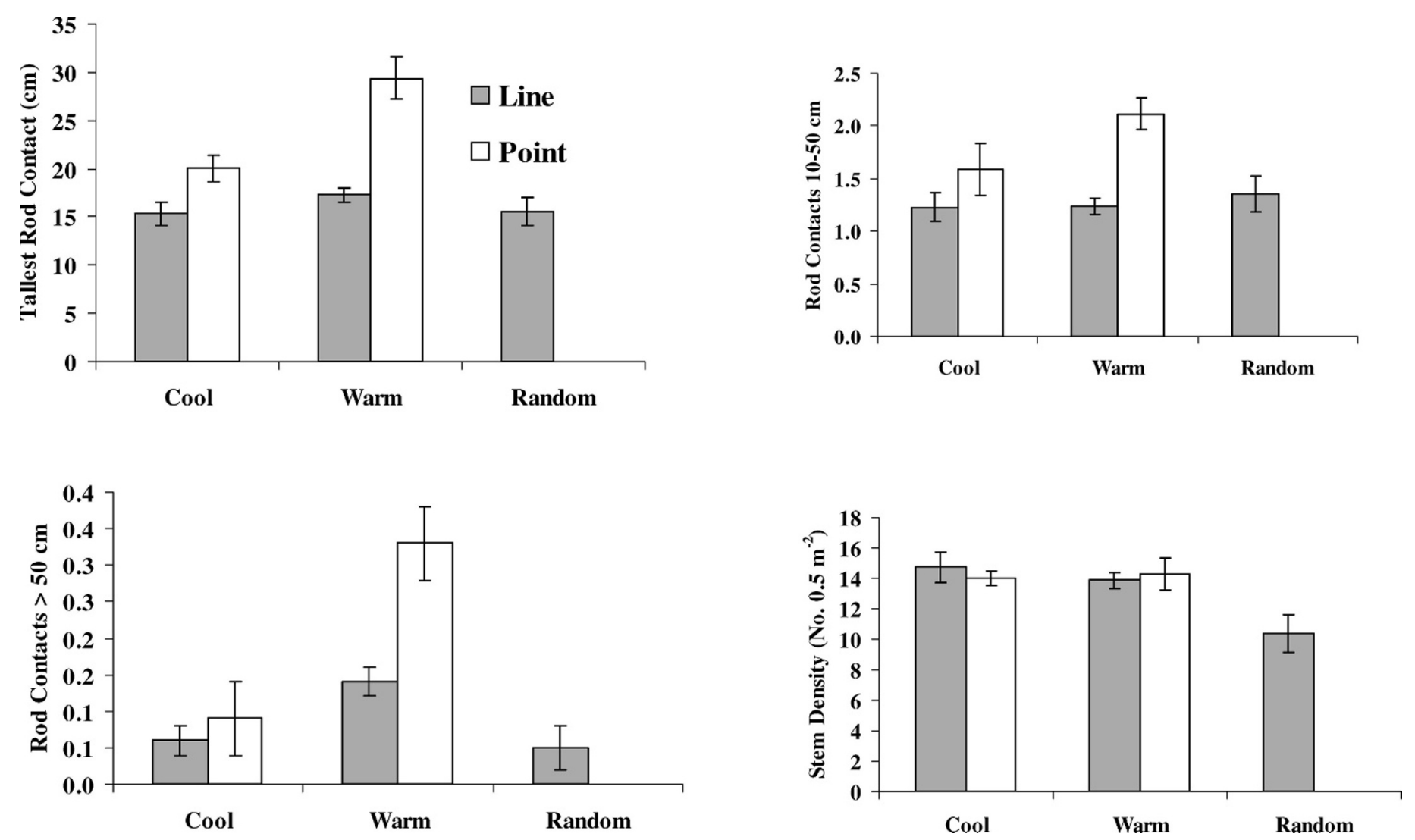

Figure 2. Differences of habitat use at multiple spatial scales and temperature categories by lesser prairie-chicken broods. Broods selected higher rod contacts (i.e., tallest rod contacts), more rod contacts $10-50 \mathrm{~cm}$ and $>50 \mathrm{~cm}$, during "warm" time periods at the point scale. The importance of sand shinnery oak is demonstrated by looking at its stem density; broods always selected higher stem densities of sand shinnery oak regardless of spatial scale or temperature. Vertical lines represent 1 standard error.

buthiuron increased basal and canopy cover contacts for grasses and decreased canopy cover and stem density for sand shinnery oak. The rate at which tebuthiuron was applied in this study rate could permanently remove the oak (Jones and Pettit 1984). Our results from 3 yr post-treatment do not bode well for the oak's recovery. Yet sand shinnery oak was consistently more abundant at brood locations, and broods were rarely seen on treated sites.

Because sand shinnery oak was improperly classified as an invasive plant (York and Dick-Peddie 1969), Texas and New Mexico, the two states with the highest historical estimates of the oak, have converted 500000 ha of shrubland to crops or pastures (Deering and Pettit 1972). Texas alone has converted over 405000 ha. Relative to the prairie-chicken's historical range, Texas now has the lowest proportion of any state of habitat occupied by the prairie-chicken (Peterson and Boyd 1998; Sullivan et al. 2000). Sand shinnery oak is not an invasive shrub. It is rhizomatous and slow to reproduce (Wiedeman and Penfound 1960). Although it has germinated successfully in a lab (Peterson and Boyd 1998), there is little documentation for germination success in the wild (Wiedeman 1960; Dhillion et al. 1994). As a result, root-killing herbicides like tebuthiuron have permanently removed the oak on many sites within the lesser prairie-chicken's range (Peterson and Boyd 1998). We are not suggesting that conversion of oak communities is the only limiting factor for prairie-chicken recovery, but we do assert that native shrubs are a critical component to their population persistence.

Data from our study support findings on leks, nests, and brood-rearing areas being associated with shrublands (Copelin 1963; Olawsky and Smith 1991; Boyd and Bidwell 2001; Fuhlendorf et al. 2002; Patten et al. 2005). Because large tracts of shrubland communities are decreasing and native shrubs drive reproductive output for ground-nesting birds (Guthery et al. 2001), the lesser prairie-chicken may go extinct if permanent losses of shrublands continue. To avoid this scenario, shrublands should be conserved at a scale consistent with prairiechicken sustainability (Fuhlendorf et al. 2002).

\section{Habitat Management Alternatives}

Our results are consistent with others (Copelin 1963; Olawsky and Smith 1991; Boyd and Bidwell 2001; Fuhlendorf et al. 2002; Patten et al. 2005; Davis 2009) that noted the significance of sand shinnery oak in providing the preferred habitat structure for lesser prairie-chickens. Alternatives to herbicides should be considered when managing the oak. For example, techniques like prescribed fire (Boyd and Bidwell 2001) or prescriptive goat browsing (Villena and Pfister 1990) could be less damaging in the long term and yet benefit multipurpose demands. A study conducted on the influence of prescribed fire on the oak in western Oklahoma found that its extent was reduced for $2-3$ yr post-fire before returning to 
structure preferred by lesser prairie-chickens for nesting and brood rearing (Boyd and Bidwell 2001). Western Oklahoma receives slightly more precipitation than southeastern New Mexico, so areas like our study site may require different burning times and frequencies. Even so, sand shinnery oak is important to the most critical life stage for lesser prairiechickens in southeastern New Mexico. Management efforts should focus on conserving oak to promote recovery of the prairie-chicken.

\section{IMPLICATIONS}

Our study found direct evidence supporting thermal selection and the dependency of lesser prairie-chicken broods on oak. Some observed habitat selection could be associated with avoidance of extreme air temperatures, but selection for greater amounts of oak occurred irrespective of temperature, suggesting that sand shinnery oak is preferred habitat for multiple reasons. Because the three management areas considered were not replicated, interpretations of our results may be limited to our study area. Nevertheless, we feel our results are valuable as a case study of how different land management schemes affect habitat use by prairie-chicken broods.

Sand shinnery oak shrublands are a unique and declining plant community within the southern Great Plains. Since sand shinnery oak has declined, rarely reproduces (Peterson and Boyd 1998), and lesser prairie-chickens are dependent on the oak, range management practices should focus on manipulating sand shinnery oak's structure temporarily. Prescribed fire is one such practice. Research has demonstrated that fire temporarily reduces sand shinnery oak and the oak will return to its previous stature 2-3 yr post-fire (Boyd and Bidwell 2001). If conservationists are to retain sand shinnery oak shrublands and species dependent on these plants, like lesser prairie-chickens, then using herbicides that can permanently eradicate sand shinnery oak should be avoided.

\section{ACKNOWLEDGMENTS}

We thank P. M. Kizer, W. L. Beggs, J. D. Weaver, and J. Williamson for property access, and J. A. Sedgwick, C. E. Braun, and three anonymous reviewers for comments that substantially improved the manuscript. L. P. Altman, C. A. Carney, D. M. Davis, C. E. Dixon, J. A. Helm, K. M. Kasik, A. Z. Miller, J. E. Montagna, D. J. Riley, F. Sakoda, C. R. Schermer, J. J. Sinclair, and T. R. Thompson assisted with trapping of prairie-chickens.

\section{LITERATURE CITED}

Balley, J. A., and S. O. Williams. 2000. Status of the lesser prairie-chicken in New Mexico. Prairie Naturalist 32:157-168.

BoYD, C. S., AND T. G. BIDWELL. 2001. Influence of prescribed fire on lesser prairiechicken habitat in shinnery oak communities in western Oklahoma. Wildlife Society Bulletin 29:938-947.

Copelin, F. F. 1963. The lesser prairie-chicken in Oklahoma. Technical Bulletin No. 6. Oklahoma City, OK, USA: Oklahoma Department of Wildlife Conservation. $58 \mathrm{p}$.

Crawford, J. A. 1980. Status, problems and research needs of the lesser prairiechicken. In: P. A. Vohs and F. L. Knopf [EDs.]. Stillwater, OK, USA: Proceedings of the 1st Prairie Grouse Symposium. p. 1-7.
Davis, D. M. 2009. Nesting ecology and reproductive success of Lesser PrairieChickens in shinnery oak-dominated rangelands. Wilson Journal of Ornithology 121:322-327.

Deering, D. W., and R. D. Pettit. 1972. Sand shinnery oak acreage survey: research highlights noxious brush and weed control. Range, Wildlife, \& Fisheries Management 2:14. Lubbock, TX, USA: Texas Tech University, College of Agricultural Sciences and Natural Resources.

Degenhardt, W. G., and K. L. Jones. 1972. A new sagebrush lizard, Sceloporus graciosus, from New Mexico and Texas. Herpetologica 28:212-217.

Dhillion, S. S., M. A. McGinley, C. F. Friese, and J. C. Zak. 1994. Construction of sand shinnery oak communities of the Llano Estacado: animal disturbances, plant community structure and restoration. Restoration Ecology 2:51-60.

Doerr, T. B., AND F. S. Guthery. 1983. Effects of tebuthiuron on lesser prairiechicken habitat and foods. Journal of Wildlife Management 47:1138-1142.

Donaldson, D. D. 1969. Effect on lesser prairie chickens of brush control in western Oklahoma [dissertation]. Stillwater, OK, USA: Oklahoma State University. $80 \mathrm{p}$.

Environmental Systems Research Institute, Inc. [computer program]. 1998. ArcView, version 3.3. Redlands, CA, USA: ESRI, Inc.

Funlendorf, S. D., A. J. W. Woodward, D. M. Leslie JR., and J. S. Shackford. 2002. Multi-scale effects of habitat loss and fragmentation on lesser prairiechicken populations of the US Southern Great Plains. Landscape Ecology 17:617-628.

GIESEN, K. M. 1994. Movements and nesting habitat of lesser prairie-chicken hens in Colorado. Southwestern Naturalist 39:96-98.

Guthery, F. S., C. L. Land, and B. W. Hall. 2001. Heat loads on reproducing bobwhites in the semiarid subtropics. Journal of Wildlife Management 65:111-117.

Harrell, W. C., and S. D. Fuhlendorf. 2002. Evaluation of habitat structural measures in a shrubland community. Journal of Range Management 55:488-493.

Harrell, W. C., S. D. Fuhlendorf, and T. G. Bidwell. 2001. Effects of prescribed fire on sand shinnery oak communities. Journal of Range Management 54:685-690.

Haukos, D. A., L. M. Smith, AND G. S. BRoda. 1990. Spring trapping of lesser prairiechickens. Journal of Field Ornithology 61:20-25.

Heady, H. F., R. P. GibBens, and R. W. Powell. 1959. A comparison of the charting, line intercept and line point methods of sampling shrub types of vegetation. Journal of Range Management 12:180-188.

IvLEv, V. S. 1961. Experimental ecology of the feeding of fishes. New Haven, CT, USA: Yale University Press. 302 p.

Johnson, K., B. H. Smith, G. Sadoti, T. B. Neville, and P. Neville. 2004. Habitat use and nest site selection by nesting lesser prairie-chickens in southeastern New Mexico. Southwestern Naturalist 49:334-343.

Jones, V. E., And R. D. Pettit. 1984. Low rates of tebuthiuron for control of sand shinnery oak. Journal of Range Management 37:488-490.

Kopp, S. D., F. S. Guthery, N. D. Forrester, and W. E. Cohen. 1998. Habitat selection modeling for northern bobwhites on subtropical rangeland. Journal of Wildlife Management 62:884-895.

Marasinghe, M. G., And W. J. Kennedy. 2008. SAS for data analysis. New York, NY, USA: Springer. $395 \mathrm{p}$.

Olawsky, C. D., AND L. M. Smith. 1991. Lesser prairie-chicken densities on tebuthiuron-treated and untreated sand shinnery oak rangelands. Journal of Range Management 44:364-368.

Patten, M. A., D. H. Wolfe, E. Shochat, and S. K. Sherrod. 2005. Effects of microhabitat and microclimate selection on adult survivorship of the lesser prairie-chicken. Journal of Wildlife Management 69:1270-1278.

Peterson, R. S., and C. S. Boyd. 1998. Ecology and management of sand shinnery communities: a literature review. Fort Collins, CO, USA: US Department of Agriculture, Forest Service, Rocky Mountain Forest and Range Experiment Station, RMRS-GTR-16. 44 p.

PetTIt, R. D. 1979. Effects of picloram and tebuthiuron pellets on sand shinnery oak communities. Journal of Range Management 32:196-200.

Riley, T. Z., C. A. Davis, M. A. Candelaria, and H. R. Suminski. 1994. Lesser prairiechicken movements and home ranges in New Mexico. Prairie Naturalist 26:183-186. 
Samson, F., and F. Knopf. 1994. Prairie conservation in North America. Bioscience $44: 418-421$

SAS InSTITUTE. 2003. SAS/STAT user's guide. Version 9.1. Cary, NC, USA: SAS Institute, Inc. 1906 p.

Schroeder, M. A., and C. E. Braun. 1991. Walk-in traps for capturing Greater Prairie-Chickens on leks. Journal of Field Ornithology 62:378-385.

Sullivan, R. M., J. P. Hughes, And J. E. Lionberger. 2000. Review of the historical and present status of the lesser prairie-chicken (Tympanuchus pallidicinctus) in Texas. Prairie Naturalist 32:177-188.

Taylor, M. A., And F. S. Guthery. 1980. Status, ecology and management of the lesser prairie chicken. Fort Collins, CO, USA: US Department of Agriculture, Forest Service, Rocky Mountain Forest and Range Experiment Station, RM-77. $15 \mathrm{p}$.

Thomas, D. L., and E. J. Taylor. 2006. Study designs and tests for comparing resource use and availability II. Journal of Wildlife Management 70:324-336.

Villena, F., and J. A. Pfister. 1990. Sand shinnery oak as forage for angora and Spanish goats. Journal of Range Management 43:116-122.
Wiedeman, V. E. 1960. Preliminary ecological study of the shinnery oak area of western Oklahoma. Norman, OK, USA: University of Oklahoma. $46 \mathrm{p}$.

Wiedeman, V. E., And W. T. Penfound. 1960. A preliminary study of the shinnery in Oklahoma. Southwestern Naturalist 5:117-122.

WiENS, J. A. 1974. Habitat heterogeneity and avian community structure in North American grasslands. American Midland Naturalist 91:195-213.

Willig, M. R., R. L. Colbert, R. D. Pettit, and R. D. Stevens. 1993. Response of small mammals to conversion of a sand shinnery oak woodland into a mixed mid grass prairie. Texas Journal of Science 45:29-43.

Woodward, A. J. W., S. D. Fuhlendorf, D. M. Leslie, and J. Shackford. 2001. Influence of landscape composition and change on lesser prairie-chicken (Tympanuchus pallidicinctus) populations. American Midland Naturalist 145:261-274

WriGHT, E. 2003. Ecological site description. Washington, DC, USA: United States Department of Agriculture Natural Resources Conservation Service. p. 1-15.

York, J. C., ANd W. A. Dick-Peddie. 1969. Arid lands in perspective. Tucson, AZ, USA: University of Arizona Press. $421 \mathrm{p}$. 